\title{
Correction to: Spatio-temporal variability of atmospheric rivers and associated atmospheric parameters in the Euro-Atlantic region
}

\author{
Venugopal Thandlam $^{1,2,3}$ (D) Anna Rutgersson ${ }^{1,2} \cdot$ Erik Sahlee $^{1}$
}

Published online: 12 November 2021

(c) The Author(s) 2021

\section{Correction to: Theoretical and Applied Climatology https://doi.org/10.1007/s00704-021-03776-w}

In this article, the labels underneath the individual panels (a, b and c) of Fig. 9 should be removed.

The original article has been corrected.

Open Access This article is licensed under a Creative Commons Attribution 4.0 International License, which permits use, sharing, adaptation, distribution and reproduction in any medium or format, as long as you give appropriate credit to the original author(s) and the source, provide a link to the Creative Commons licence, and indicate if changes were made. The images or other third party material in this article are included in the article's Creative Commons licence, unless indicated otherwise in a credit line to the material. If material is not included in the article's Creative Commons licence and your intended use is not permitted by statutory regulation or exceeds the permitted use, you will need to obtain permission directly from the copyright holder. To view a copy of this licence, visit http://creativecommons.org/licenses/by/4.0/.

Publisher's note Springer Nature remains neutral with regard to jurisdictional claims in published maps and institutional affiliations.

The online version of the original article can be found at https:// doi.org/10.1007/s00704-021-03776-w

Venugopal Thandlam

venu.thandlam@geo.uu.se

1 Department of Earth Sciences, Uppsala University, Uppsala, Sweden

2 Centre of Natural Hazards and Disaster Science, Uppsala University, Uppsala, Sweden

3 Centre for Environment and Development Studies (CEMUS), Uppsala University, Uppsala, Sweden 